\title{
Study on the Status Quo and Countermeasures of Rural Domestic Waste Pollution in Liaoning Province
}

\author{
Qi $\mathrm{Li}^{1,2,3,4}$, Shu Xiaoxiao ${ }^{1,2,3,4}$ \\ ${ }^{1}$ Shaanxi Provincial Land Engineering Construction Group Co., Ltd., Xi'an, China \\ ${ }^{2}$ Institute of Land Engineering and Technology, Shaanxi Provincial Land Engineering Construction Group Co., Ltd., Xi'an, China \\ ${ }^{3}$ Shaanxi Provincial Land Consolidation Engineering Technology Research Center, Xi'an, China \\ ${ }^{4}$ Key Laboratory of Degraded and Unused Land Consolidation Engineering, the Ministry of Land and Resources, Xi'an, China
}

\begin{abstract}
At present, the problem of rural domestic garbage pollution in China is relatively serious, which restricts the sustainable development of rural areas. Therefore, it is very important to investigate and analyze the characteristics of rural domestic garbage generation and discuss countermeasures for the treatment of domestic garbage. This article is conducted a one-year follow-up survey of the characteristics of garbage generation in Zhenshang Village, Central Village, and Natural Village in Fushun City, Anshan City, Dandong City, Shenyang City, Tieling City, and Panjin City in Liaoning Province. Background, the amount, physical composition and change trend of rural domestic garbage were analyzed, and on this basis, countermeasures for rural domestic garbage treatment in Liaoning Province were proposed.
\end{abstract}

\section{Introduction}

With the continuous development of new rural construction, the appearance of rural villages and villages in China is undergoing tremendous changes, and the living standards of farmers have continued to improve. Products have entered the lives of farmers, but the resulting "white pollution" has become increasingly serious ${ }^{[1]}$, and rural household waste has also increased. If the rural domestic garbage is not effectively treated, it will not only affect the rural landscape, but also cause harm to health.

The report of the 17th National Congress of the Communist Party of China puts emphasis on the construction of ecological civilization, and the report of the 18th National Congress of the Communist Party of China further states that it is necessary to vigorously promote the construction of new countryside. As an old industrial base in Northeast China, Liaoning is located in the southernmost part of Northeast China and is rich in resources. In recent years, with the continuous promulgation of various national policies, infrastructure has been greatly improved. However, due to the entrenched lifestyle, there are still big problems in rural waste disposal. The comprehensive treatment of rural domestic waste in the rural environment is one of the more important issues. It is an important step to promote the construction of a new countryside and a harmonious socialist society. Harmonious society is of great significance.

\section{Overview of the study area}

Liaoning Province is located in northeastern China and is an important part of the Bohai Rim Economic Belt and the Northeast Economic Zone. The geographical location is between $43^{\circ} 26^{\prime}$ to $38^{\circ} 43^{\prime}$ north latitude and $125^{\circ}$ $46^{\prime}$ to $118^{\circ} 53^{\prime}$ longitude east. There are 14 cities in Liaoning Province, with a regional land area of 145,900 $\mathrm{km}^{2}$, accounting for $1.5 \%$ of China's total land area. It belongs to a temperate continental monsoon climate zone with an average annual temperature of 7 to $11^{\circ} \mathrm{C}$ and a frost-free period of more than 150 days. In this study, Hou'an Village and Shangma Township, Hou'an Town, Fushun County, Fushun City, Liaoning Province, Dagushan Town, Qianshan District, Anshan City, Hushan Town, Kuandian County, Dandong City, Damintun Town, Xinmin City, Shenyang City, and Changling City, Tieling City Changtu Town of Tu County and Desheng Town of Panshan County of Panjin City serve as the research areas.

\section{Analysis of the status of rural domestic garbage in Liaoning Province}

\subsection{Status of rural domestic waste in typical areas of Liaoning Province}

Each city (township) selects the village where the town government is located, the central village and the natural village, and then selects typical farmers based on income levels. According to the annual income per capita in 2014, ten households were selected from each of the three income levels of the high, middle and low income levels to conduct household waste production survey and analysis. Based on two types of survey data: the daily production of rural garbage in the study area and the total population at the survey site, the per capita waste 
production at the survey site can be calculated. The results are shown in Table 1.

Table 1 Statistics of domestic garbage production in rural sampling sites in Liaoning Province in 2014

\begin{tabular}{|c|c|c|c|c|c|c|c|}
\hline Township & Village & $\begin{array}{c}\text { Survey } \\
\text { household } \\
\text { s } \\
\text { Number } \\
\text { (househol } \\
\text { d) } \\
\end{array}$ & $\begin{array}{l}\text { Investigat } \\
\text { or } \\
\text { number }\end{array}$ & $\begin{array}{c}\text { Amount of } \\
\text { garbage } \\
(\mathrm{kg} / \mathrm{d})\end{array}$ & $\begin{array}{c}\text { Daily } \\
\text { production per } \\
\text { capita } \\
(\mathrm{kg} /(\mathrm{d} \cdot \text { people } \\
())\end{array}$ & $\begin{array}{c}\text { Total } \\
\text { populati } \\
\text { on } \\
\text { number }\end{array}$ & $\begin{array}{c}\text { Total } \\
\text { waste } \\
\text { productio } \\
\mathrm{n}(\mathrm{kg} / \mathrm{d})\end{array}$ \\
\hline $\begin{array}{l}\text { Hou'an Town, } \\
\text { Fushun County }\end{array}$ & $\begin{array}{l}\text { Hou'an } \\
\text { Village }\end{array}$ & 10 & 36 & 33.84 & 0.94 & 1935 & 1818.9 \\
\hline $\begin{array}{c}\text { Shangma } \\
\text { Township, } \\
\text { Fushun County }\end{array}$ & $\begin{array}{l}\text { Tunche } \\
\text { village }\end{array}$ & 10 & 35 & 35.35 & 1.01 & 602 & 608.02 \\
\hline $\begin{array}{c}\text { Shangma } \\
\text { Township, } \\
\text { Fushun County }\end{array}$ & $\begin{array}{l}\text { Kammu } \\
\text { Village }\end{array}$ & 10 & 33 & 17.16 & 0.52 & 983 & 511.16 \\
\hline $\begin{array}{c}\text { Dagushan Town, } \\
\text { Qianshan }\end{array}$ & $\begin{array}{l}\text { Dagushan } \\
\text { Village }\end{array}$ & 10 & 37 & 34.41 & 0.93 & 1236 & 1149.48 \\
\hline $\begin{array}{c}\text { Dagushan Town, } \\
\text { Qianshan }\end{array}$ & $\begin{array}{l}\text { Zhangziwo } \\
\text { Village }\end{array}$ & 10 & 35 & 35.15 & 0.89 & 1342 & 1194.38 \\
\hline $\begin{array}{c}\text { Dagushan Town, } \\
\text { Qianshan }\end{array}$ & $\begin{array}{l}\text { Huamaitun } \\
\text { Village }\end{array}$ & 10 & 35 & 22.4 & 0.64 & 1812 & 1159.68 \\
\hline $\begin{array}{l}\text { Hushan Town, } \\
\text { Kuandian } \\
\text { County }\end{array}$ & $\begin{array}{l}\text { Red Rock } \\
\text { Village }\end{array}$ & 10 & 36 & 26.64 & 0.74 & 1232 & 911.68 \\
\hline $\begin{array}{l}\text { Hushan Town, } \\
\text { Kuandian } \\
\text { County }\end{array}$ & $\begin{array}{l}\text { Hushan } \\
\text { Village }\end{array}$ & 10 & 34 & 26.18 & 0.77 & 2858 & 2200.66 \\
\hline $\begin{array}{c}\text { Hushan Town, } \\
\text { Kuandian } \\
\text { County }\end{array}$ & $\begin{array}{l}\text { Nanlingwai } \\
\text { cun }\end{array}$ & 10 & 33 & 18.81 & 0.57 & 478 & 272.46 \\
\hline $\begin{array}{c}\text { Xinmin } \\
\text { Damintun Town }\end{array}$ & $\begin{array}{l}\text { Kerchief } \\
\text { cow village }\end{array}$ & 10 & 39 & 40.56 & 1.04 & 2815 & 2927.6 \\
\hline $\begin{array}{c}\text { Sujiatun } \\
\text { Xianggou } \\
\text { Township }\end{array}$ & $\begin{array}{l}\text { Victory } \\
\text { Village }\end{array}$ & 10 & 36 & 5.28 & 0.88 & 1106 & 973.28 \\
\hline $\begin{array}{l}\text { Changtu Town, } \\
\text { Changtu County }\end{array}$ & $\begin{array}{l}\text { Qingyang } \\
\text { Village }\end{array}$ & 10 & 33 & 17.82 & 0.54 & 2240 & 1209.6 \\
\hline $\begin{array}{l}\text { Changtu Town, } \\
\text { Changtu County }\end{array}$ & $\begin{array}{l}\text { Sun } \\
\text { Mountain } \\
\text { Village }\end{array}$ & 10 & 35 & 24.5 & 0.7 & 2566 & 1796.2 \\
\hline $\begin{array}{l}\text { Changtu Town, } \\
\text { Changtu County }\end{array}$ & $\begin{array}{l}\text { Erdaogou } \\
\text { Village }\end{array}$ & 10 & 37 & 20.35 & 0.55 & 2725 & 1498.75 \\
\hline $\begin{array}{l}\text { Desheng Town, } \\
\text { Panshan County }\end{array}$ & $\begin{array}{l}\text { Victory } \\
\text { Village }\end{array}$ & 10 & 35 & 49 & 1.4 & 1945 & 2723 \\
\hline $\begin{array}{l}\text { Desheng Town, } \\
\text { Panshan County }\end{array}$ & $\begin{array}{l}\text { Sanke } \\
\text { Village }\end{array}$ & 10 & 35 & 42 & 1.2 & 1720 & 2064 \\
\hline
\end{tabular}

According to survey statistics, it is found that the daily average daily production of rural garbage in sampled villages is between 0.52 and $1.4 \mathrm{~kg}$. The largest daily output of domestic garbage is Desheng Village, Desheng Town, Panshan County, which is $1.4 \mathrm{~kg}$ per person per day. The least area is Shangmao, Fushun County. In the village of Kanmu, it is $0.52 \mathrm{~kg}$; the per capita daily output of domestic garbage in different regions and villages varies widely, and the average per capita daily output of garbage in the study area is $0.83 \mathrm{~kg}$.
By correlating it with the economic level, it can be found that the amount of rural domestic waste produced can reflect the level of economic development in the region to a certain extent. The two present a positive correlation, that is, the higher the regional economic level, the more waste generated many. 


\subsection{Status of Rural Domestic Waste Treatment in Liaoning Province}

The so-called treatment of rural domestic garbage is to quickly remove the rural domestic garbage and make it harmless, and finally use it reasonably to achieve resource utilization, harmlessness and reduction. The treatment of rural domestic garbage involves a series of activities, including the generation, treatment and utilization of garbage. Dealing with rural garbage is a long-standing problem, but it has not received enough attention. With the emphasis on new rural construction, more and more people are aware of the importance of this issue. However, due to various factors, the problem of rural garbage disposal has not been effectively resolved.

At present, there are three main methods of garbage disposal in rural areas in Liaoning Province ${ }^{[2]}$, which are compost, landfill and incineration. Each of the three methods has its own characteristics, with advantages and disadvantages coexisting ${ }^{[3]}$.

Table 2 Waste treatment methods in rural Liaoning

\begin{tabular}{|c|c|c|}
\hline $\begin{array}{c}\text { Processing } \\
\text { method }\end{array}$ & advantage & Disadvantage \\
\hline Landfill & $\begin{array}{c}\text { Large processing capacity } \\
\text { Lower cost } \\
\text { Simple processing technology }\end{array}$ & $\begin{array}{l}\text { Large footprint } \\
\text { Easily pollute underground resources }\end{array}$ \\
\hline $\begin{array}{c}\text { Compostin } \\
\mathrm{g}\end{array}$ & $\begin{array}{c}\text { Easier location } \\
\text { Lower processing costs } \\
\text { Can produce soil improvers }\end{array}$ & $\begin{array}{l}\text { Difficult to control process conditions } \\
\text { Poor treatment efficiency may contaminate } \\
\text { soil } \\
\text { Can only deal with organic matter that } \\
\text { increases waste }\end{array}$ \\
\hline $\begin{array}{c}\text { Incineratio } \\
\mathrm{n}\end{array}$ & $\begin{array}{l}\text { Small footprint and high processing efficiency } \\
\text { High degree of reduction, can reduce volume by } \\
990 \% \\
\text { High degree of harmlessness, solid residue can be } \\
\text { recycled } \\
\text { Burning heat as energy }\end{array}$ & $\begin{array}{l}\text { Big investment } \\
\text { High operating costs } \\
\text { Generate air pollution }\end{array}$ \\
\hline
\end{tabular}

\section{Main Problems Existing in the Treatment of Rural Domestic Waste in Liaoning Province}

\subsection{Weak environmental awareness of rural residents}

China's rural areas have developed rapidly since the reform and opening up, but this is only reflected in the material aspect. At the same time, the material level has improved, the peasants' living habits have not changed with them. They still follow the previous lifestyle, and there is generally a random discard of garbage, Seems very casual on the issue of garbage management. There is no awareness of garbage disposal, because the harm caused by rural garbage is not realized.

\subsection{Not applicable for waste disposal regulations}

The current laws and regulations do not set requirements and regulations for the treatment of rural domestic waste, and there are no successful cases in the treatment of rural waste. Many rural waste treatment methods are imitating cities and do not take into account the special characteristics of rural waste.

\subsection{Waste treatment methods are backward}

In order to achieve the purpose of rural domestic waste disposal as soon as possible, most rural areas in Liaoning Province adopt simple methods such as simple landfilling, incineration, or direct return to the field. Although these methods increase the speed of garbage disposal, they also bring to the rural living environment. Severe pollution and the quality of treatment is not high.

\subsection{Lagging of infrastructure construction}

Township environmental protection infrastructure is an important realistic support for the treatment of rural domestic waste, with a strong social welfare component. At present, it mainly depends on the input of the Liaoning Provincial Government. However, Liaoning Province's current economic foundation is weak and the local government's limited financial resources are not enough to support the construction of all township infrastructure. In the construction of new rural villages, the limited financial resources are mainly concentrated in the construction of roads, houses, water supply, power supply, etc., and most of the environmental protection facilities such as garbage treatment, drainage, and centralized sewage treatment are not considered, and they are seriously behind rural construction. scale. 


\section{Countermeasures to Solve Rural Domestic Garbage in Liaoning Province}

\subsection{Strengthening publicity and education in rural environmental protection}

The treatment of rural domestic garbage must rely on the vast number of farmers, and the government's efforts alone will not work ${ }^{[4]}$. Therefore, we must vigorously publicize environmental protection knowledge to farmers and strengthen their environmental awareness. We can start from the following three aspects. First, strengthen environmental education for primary and middle school students so that students develop good living habits. Second, regularly hold environmental publicity and publicity seminars in central towns or villages to increase communication efforts. Third, the government must speed up and improve the rural environmental protection system.

\subsection{Strengthen government supervision and improve environmental protection regulations}

Strengthen rural environmental supervision, strengthen supervision of relevant departments in the process of environmental protection supervision and law enforcement, so that relevant departments such as environmental protection management and law enforcement can really do their work. We will improve policies and regulations for the treatment of rural domestic garbage, and strengthen the systematic construction of rural domestic garbage treatment.

\subsection{Building and cultivating excellent environmental improvement talent teams}

Strengthen vocational skills training for environmental improvement practitioners, improve environmental protection education in colleges and universities, and build an ecological society ${ }^{[5]}$. The core of environmental education is to improve people's environmental awareness through the practical activities of education. With the continuous development of the domestic economy, the direction of social development has changed from the original industrial civilization to the pursuit of ecological civilization. Therefore, strengthening the establishment of related disciplines is also an inevitable trend.

\section{References}

1. Wang Jin, Li Dinglong, Zhang Feng'e. Status and existing problems of characteristic treatment of urban domestic waste in Jiangsu Province [J]. Environmental Science and Technology, 2006 (12).

2. Jiang Shumei.Countermeasures for Rural Domestic Waste Treatment $[\mathrm{J}]$.Science and Technology Information, 2008 (1).
3. Dongxing G, Cheng Q. Preliminary Research of the Situation and Countermeasures of Pollution of Rural Domestic Garbage $[\mathrm{J}][\mathrm{J}]$. China Resources Comprehensive Utilization, 2008, 8.

4. Chen K B, He S Y, Feng H J. Study on the characteristic of rural domestic garbage in Zhejiang[J]. Energy Engineering, 2010, 1: 39-43.

5. Junqi W, Youbin W, Xiaocui L, et al. Discharge \& disposal status on domestic garbage and sewage in countrysides[J]. Chinese Journal of Public Health Engineering, 2004, 3(4): 202-205. 